\title{
Experience herb relocation for preserving its population during reconstruction period
}

\author{
Anton Martsev ${ }^{1}$ and Oleg Selivanov ${ }^{1} *$ \\ ${ }^{1}$ Vladimir State University named after A.G. and N.G. Stoletovs', Gorky Street 87, Vladimir, \\ 600000, Russia
}

\begin{abstract}
The article is devoted to the experience of transplantation Anemone nemorosa L., listed in the Red book of the Vladimir region as a rare species (status category - 3). A feature of this work is transplanting in the autumn period, in connection with the construction of a natural place of growth, in accordance with the conclusion of environmental impact assessment. The aim of the work was to preserve the aboriginal population in natural conditions that are close in their ecological characteristics to the natural place of growth and which do not fall into the zone of reconstruction. Methods. We used the geobotanical description method, soil selection methods, and laboratory methods. Results. The data of the geobotanical description of the initial and recipient habitats of the Anemone nemorosa and soil characteristics are presented. The method of plant transplantation is described in detail. Conclusion. The phenollogical observations made in May 2019 showed that Anemone nemorosa successfully transferred the autumn transplant to a new place. An artificial population of Anemone oakwood was formed, which requires further monitoring studies for adaptation and resistance to transplantation.
\end{abstract}

\section{Introduction}

Due to the anthropogenic impact intensification on natural ecosystems, the biodiversity conservation is a vital problem of modern science. Flora creates the necessary human environment and provides most biological and social needs. Therefore, despite other wildlife components, it is considered to be national wealth requiring preservation, enrichment and rational use. Priority attention in this respect should be given to the most vulnerable plants - rare species of the wild flora [1].

The measures development for preserving the biological diversity of rare and endangered plants of native flora should be based on the notion of ecological, biological and reproductive features of species, ultimately determining their population conservation and renewal [2-4]. Therefore, the plants transfer from their natural habitat, planned for the future anthropogenic transformation (construction, deforestation, raw materials exploration, etc.) to the places similar in the environmental factors should be carried out only after appropriate scientific justification. Stable self-renewing population with the natural resources conservation of the gene pool can be created only with a sufficient number of

*Corresponding author: martsevaa@yandex.ru 
replanted specimen so such research is justified only in the case of potential loss of the natural population (rare protected species) [5-6].

The paper describes the relocation experience of Anemone nemorosa L. population in the Vladimir region from the area planned for reconstruction (construction) in order to preserve the herb. The research novelty highlights the first testing of Anemone nemorosa replanting approach in autumn.

\section{Materials and methods}

The research object is Anemone nemorosa, a perennial herb 8- $25 \mathrm{~cm}$ high, having fleshy rhizome and single long-stemmed basal leaf. The rhizome branches and grows rapidly thus forming dense thickets. Spring ephemeroid, blooms in April-May, fruits ripen in June. It requires moisture and often prefers damp habitats, though it is very photophilous and grows well in full sunlight. Seed productivity is rather high, but their field germination is low, and seedlings require long period for gaining strength and blooming (10 years or more), thus the main reproduction method of the plant is still vegetative. It is well developing on moderately acidic soils (at $\mathrm{pH} 4.5-6$ ). The Anemone nemorosa population is known to increase by several times even under adverse environmental conditions.

In the Vladimir region, Wood anemone is listed in the Red book as a rare species (status category - 3). Its locations in Gus-Khrustalny, Melenki, Petushky, Sobinka and YurievPolsky districts of the region are detected for certain.

The site of Anemone nemorosa natural population was located in the Gus-Khrustalny district of the Vladimir region in the area of the planned petrol pipeline reconstruction. This region is located in the North-Eastern part of the Meshchera lowland and is characterized by high waterlogging and woodiness (mainly coniferous and mixed forests). The climate is moderately continental. Soils are sod-podzolic sandy loam.

In spring of 2018 engineering and environmental surveys were conducted in the reconstruction area. The received information was later used for carrying out our research. Basing on the considerations that Wood anemone grows in dense flower-beds in the amount of about 100 plants per $1 \mathrm{~m}^{2}$, it was revealed that about 3000 plant specimens grow in this area.

According to the published data, Anemone nemorosa refers to the species highly resistant to the introduction into the culture [7-12], as well as to reintroduction into the nature. Therefore in order to preserve the native population, it was decided to replant it outside the construction area. Due to the time limits, early autumn season and the part of the reconstruction, the plants were replanted early October 2018. The permission for the introduction work was received from the Unified Directorate of the especially protected areas of the Vladimir region. The reintroduction place was selected outside the renovation area by the third party conducting engineering and environmental surveys $\left(36^{\text {th }}\right.$ block forest mensuration part 19 of Davydov district forestry, track "Znamya truda" of the GusKhrustalny district). The location corresponded to the ecological and phytocoenotic conditions of the sites suitable for replanting (required shading availability, no stagnant moisture or drying). Further, the replanting site was agreed with Gus-Khrustalny forestry.

Geobotanical description was done. Cation-anion analysis of soil from the plantation area and the intended replanting site was also carried out.

The soil was sampled using the envelope method from the depth of $10-15 \mathrm{~cm}$.

Cation-anionic composition of the aqueous soil extracts was determined by capillary electrophoresis using the device "Kapel-104" (PND F 16.1:2: 2.3:2.2.69-10 and PND F $16.1: 2: 2.2: 2.3 .74-2012$ )

The aqueous soil extraction $\mathrm{pH}$ was determined by the potentiometric method applying the liquids analyzer "Expert-001-3". 


\section{Results}

The vegetation community of the original habitat of Wood Anemone population was characterized by the following indicators. The tree stand of 6B2Ald1Asp1P_composition is formed mainly by Betula pubescens Ehrh. and Alnus glutinosa (L.) Gaertn of $25 \mathrm{~cm}$ average diameter and height of $18-24 \mathrm{~m}$, the stand closeness is 0.7 , the composition also includes single Populus tremula L. and Pinus sylvestris L. of up to $35-40 \mathrm{~cm}$ diameter. The undergrowth is rare, 1-4 m high, formed by Picea abies (L.) Karst and Populus tremula L. the undergrowth of the latter forms medium-density groups at the forest edges. The boskage is dense, 1,3-4 m high, with dominating Sorbus aucuparia L., also including Padus avium Mill., Frangula alnus Mill., Ribes nigrum L., Rubus idaeus L., shrubby Salix cinerea L. and Salix aurita $L$. The herb-shrubby layer has a significant overall projective coverage (OPC) 70-90\%, with dominating Stellaria holostea L., Oxalis acetosella L., Viola palustris L., Equisetum sylvaticum L., Fragaria vesca L., Ajuga reptans L., Geum rivale L., Ranunculus acris L., Dryopteris carthusiana (Vill.) H.P.Fuchs, Dryopteris filix-mas (L.) Schott, Betonica officinalis L., Lathyrus vernus (L.) Bernh., including also Stachys palustris L., Aegopodium podagraria L., Urtica dioica L., Filipendula ulmaria (L.) Maxim., Ficaria verna Huds., Succisa Haller, Melampyrum nemorosum L.. The moss cover is poorly developed, represented by green mosses cushions and groups, OPC $40 \%$.

The recipient habitat, selected for replanting Wood Anemone population, was chosen basing on similar physiognomy and species composition of vegetation, soil and hydrological conditions. It is located at about $1 \mathrm{~km}$ distance from the original place, and is characterized by the following features. The tree stand of $7 \mathrm{~B} 2 \mathrm{Ald} 1 \mathrm{P}+\mathrm{Sp}$ composition is formed mainly by Aetula pubescens and Populus tremula with $22 \mathrm{~cm}$ average diameter and 16-20 m height, the stand closeness is 0.7. Its composition also includes Picea abies with $18 \mathrm{~cm}$ diameter and Pinus sylvestris with the diameter of about $35 \mathrm{~cm}$. The undergrowth is rare, 1-4 m high, formed by Picea abies and Populus tremula, the undergrowth of the latter forms medium-density groups at the forest edges. The undergrowth is dense, 1,3-4 m high, with dominating Sorbus aucuparia, Prunus padus L., Frangula alnus, Rubus idaeus, shrub willows (Salix cinerea and Salix aurita) are also noted. The grass-shrubby layer has significant overall projective coverage (OPC) of 70-90\%, with dominating Stellaria holostea, Oxalis acetosella, Viola palustris, Equisetum sylvaticum, Fragaria vesca, Ajuga reptans, Geum rivale, Ranunculus acris, Dryopteris carthusiana, Betonica officinalis, Lathyrus vernus, including also Aegopodium podagraria, Melampyrum nemorosum. Moss cover is poorly developed, represented by green mosses cushions and groups, OPC $40 \%$. In general, the habitat can be described as better drained, which, in this case, was a positive factor, since it reduced possible competition with wet-grass high-grass species (Urtica dioica, Filipendula ulmaria) and negative impact of seasonal waterlogging (soaking). For replanting into this habitat, the site with the locally rarefied stand was selected.

Prior the plant relocation, we have selected and conducted laboratory studies of soil sampled in the original and replantation places regarding cation-anion composition and $\mathrm{pH}$ of their aqueous extracts. The research results are presented in table.

Table 1. Cationic-anionic composition and $\mathrm{pH}$ of aqueous extract of soils

\begin{tabular}{|c|c|c|c|c|c|c|c|c|c|c|c|}
\hline \multirow{2}{*}{$\begin{array}{c}\text { Soil } \\
\text { sample }\end{array}$} & \multirow{2}{*}{$\begin{array}{l}\mathrm{pH}, \\
\text { un. }\end{array}$} & \multicolumn{10}{|c|}{ The content of cations and anions, $\mathrm{mg} / \mathrm{l}$} \\
\hline & & $\mathrm{NH}_{4}^{+}$ & $\mathrm{Na}^{+}$ & $\mathrm{K}^{+}$ & $\mathrm{Mg}^{2+}$ & $\mathrm{Ca}^{2+}$ & $\mathrm{Cl}^{-}$ & $\mathrm{SO}_{4}{ }^{2-}$ & $\mathrm{NO}_{3}{ }^{-}$ & $\mathrm{F}^{-}$ & $\mathrm{PO}_{4}{ }^{2-}$ \\
\hline $\begin{array}{c}\text { Natural } \\
\text { growth } \\
\text { place }\end{array}$ & 4.0 & 1.99 & 15.6 & 7.00 & 1.50 & 6.01 & 22.7 & 3.13 & 23.7 & 0.1 & 0.57 \\
\hline $\begin{array}{c}\text { Planting } \\
\text { site }\end{array}$ & 6.1 & 1.07 & 27.3 & 10.3 & 1.92 & 6.10 & 38.9 & 4.26 & 3.09 & 0.3 & 0.16 \\
\hline
\end{tabular}


Water-soluble compounds in soil, which are the source of cations and anions, play an important role in the plants life. For example, ammonium sulfate and magnesium sulfate promote seed germination. Chloride ions, in the form of calcium and magnesium salts, play an important role in the metabolic processes in plants, and their increased concentration causes premature drying. Calcium and magnesium cations contribute to the physiological processes activation in plants. The excess concentrations, the presence or absence of any water-soluble cation or anion in soil, can significantly affect the plant development and viability. The research results show that cation-anionic composition of soils aqueous extracts differ significantly in the ions number. The soil $\mathrm{pH}$ is different, but the obtained results were optimal for Anemone nemorosa growth and development.

Thus, the technology of Anemone nemorosa replanting is put forward in the foreground, primarily due to the autumn period specifics (low air temperatures, short daylight hours, high soil humidity, etc.). Taking into account all these features of the working period, we applied the following step-by-step approach:

1. The relocation site for Anemone nemorosa was prepared including its clearing from dead wood and soil top layer removing ( $25 \mathrm{~cm}$ depth).

Basing on the necessity to replant 3,000 plant specimens, using data from the engineering and environmental surveys that Wood Anemone grows in natural habitat forming dense flower-beds amounting about 100 plants per $1 \mathrm{~m}^{2}$, a pilot plot of $3 \mathrm{~m} \times 10 \mathrm{~m}$ was prepared for their replanting.

2. Removing the soil top layer containing vegetative organs of Anemone nemorosa from the area planned for the reconstruction.

- The soil top layer removal of approximate area $25 \times 25 \times 25 \mathrm{~cm}$.

The soil layer height was determined empirically. At the beginning, several Wood anemone rhizomes were selected to define the roots size. It is required, as otherwise, when cutting the turf, it is possible to damage the rhizomes causing the entire population dying.

- Laying the soil top layer, containing Anemone nemorosa vegetative organs onto the

plastic bags for their transfer and loading into the vehicle.

3. Transportation to the replanting site and unloading.

4. Laying the soil top layer containing Anemone nemorosa vegetative organs in the prepared areas according to the "lawn principle" tightly to each other.

It is worth noting that the soil layer removal with the plants vegetative organs, as well as further transportation (strictly without damaging the soil layer structure) and laying it in a new place was carried out within one day to prevent the cut soil over-drying. And the "lawn principle" laying meant no gaps between the soil fragments (in case of their formation, they were filled with soil from the original place). No artificial watering and fertilizing was done.

Early May 2019, during a control visit to the Anemone nemorosa replanting site, the plant vegetative shoots were found. No plant vegetative shoots outside the replanting area were found. In connection with the early spring in the European part of Russia that year, the plant for this period almost faded and fruits were found.

\section{Conclusion}

Thus, it was revealed that Anemone nemorosa was successfully relocated into a new place characterized by less acidic soil and increased $\mathrm{Na}, \mathrm{K}$ and $\mathrm{Cl}$ compounds concentration, reduced content of $\mathrm{NO}_{3}{ }^{-}$and $\mathrm{PO}_{4}{ }^{2-}$ anions, and similar content of $\mathrm{Ca}^{2+}, \mathrm{Mg}^{2+}$ and $\mathrm{SO}_{4}{ }^{2-}$ ions. The artificial population of Anemone nemorosa has been formed, which requires further monitoring of its adaptation and resistance to relocation. These measures are planned jointly with the Unified Directorate of protected areas. To assess the replanted herbs vital activity, it is planned to carry out operations including the following evaluation aspects: 
- herbs condition (dying, oppression, normal, good);

- plant height (compared to the average height of the same species growing in nearby natural complexes);

- blooming and number of flowers (compared to the average for the same species growing in nearby natural complexes);

- fruiting, the number of fruiting herbs (in comparison with the average values of the same species growing in the nearest natural complexes).

To support and increase the effectiveness of such work, specialized state organizations should give the protected status of botanical micro-stores places of transplantation.

\section{References}

1. N. Gaponenko, A. Gnatyuk, Bulletin of the Botanical Garden-Institute, 15, 13 - 15 (2016).

2. I. Loznuho, V. Danilyuk, V. Linnik, T. Koncevaya, Proceedings of Interregional Science Conference "Botanical Gardens: state and prospects of conservation, study and use of the biological diversity of the plant world, 171 (2002).

3. A. Gnatyuk, M. Gaponenko, Introductions, saving and monitoring roslinnogo riznomanittya, 33 (2014).

4. R. Saodatova, T. Konovalova, A. Ershova, A. Shvetsov, Bulletin of the Main Botanical Garden, 1 (203). 3-14 (2017).

5. T. Trifonova, A. Podolets, O. Selivanov, A. Martsev Theoretical and Applied Ecology, 2, 94-101 (2018)

6. A. Martsev, O. Selivanov E3S Web of Conferences, 135, 01047 (2019)

7. K.Van der Biest, P. Meire, T. Schellekens, B. D'hondt, D. Bonte, T.Vanagt, TomYsebaert, Science of The Total Environment, 71210, 136350 (2020)

8. M. Shalizi, S. Khurram, J. Groninger, K. Akamani, R. Morrissey Global Ecology and Conservation 22, e00942 (2020)

9. A.V. Chechevichkin, N.I. Vatin, V.V. Samonin, M.A. Grekov. Magazine of Civil Engineering 76(8), 201-213 (2017). DOI:10.18720/MCE.76.18.

10. V. Chechevichkin, N. Vatin. Megacities land drainage and land runoff features and treatment. Applied Mechanics and Materials, 641-642, 409-415 (2014). DOI:10.4028/www.scientific.net/AMM.641-642.409.

11. V.N. Chechevichkin, N.I. Vatin. Magazine of Civil Engineering 50(6), 67-74 (2014). DOI:10.5862/MCE.50.7.

12. E.R. Yagmurov, G.V Kozlov, M.A. Pushkarev, Journal of Hygienic Engineering and Design 20, 60-69 (2017). 